\title{
ENERGETICKÁ ÚSPORA JEDNODUCHÉHO PODTLAKOVÉHO VĚTRÁNÍ S VYÚSTĚNÍM DO EXTERIÉRU PřED SÁNÍ TEPELNÉHO ČERPADLA - PŘÍPADOVÁ STUDIE
}

\author{
ENERGY SAVINGS SIMPLE VACUUM VENTILATION WITH END TO \\ THE EXTERIOR BEFORE THE HEAT PUMP SUCTION - A CASE STUDY
}

\author{
Dominik Cak1 ${ }^{*}, 1$, Ondřej Nespěšný, Jan Vystrčil
}

*cakl.d@vutbr.cz

${ }^{1}$ Fakulta Stavební VUT v Brně, Veveří 331/95, 60200 Brno-střed

\begin{abstract}
Abstrakt
Stále se zvyšující nároky na těsnost obálky budovy vyžadují z hygienických požadavků pravidelné větrání okny, nebo s ohledem na uživatelský komfort vzduchotechnickou jednotkou, která umožňuje zpětné získávání tepla. Vzduchotechnické jednotky s rekuperací tepla mají vysoké pořizovací náklady, obzvláště pokud obsahují tepelné čerpadlo. Stále se zvyšující nároky na využití primární energie z neobnovitelných zdrojů způsobují, že se v objektu vyskytuje technologie tepelného čerpadla. Ekonomicky výhodnou alternativou může být jednoduché podtlakové větrání domu, kde odpadní vzduch z interiéru je vyústěn přímo před sání tepelného čerpadla. Vzhledem k lepším pracovním podmínkám (teplejší a vlhčí odváděný vzduch) může tepelné čerpadlo obvykle dosahovat vyšších sezonních topných faktorů.
\end{abstract}

\section{Klíčová slova}

Energetická náročnost budov, vzduchotechnika, distribuce vzduchu, jednoduché podtlakové větrání, sání tepelného čerpadla

\begin{abstract}
The ever-increasing demands on the airtightness of building envelope require regular ventilation of the windows for hygienic requirements, or with regard to user comfort an air handling unit that allows heat recovery. Air handling units with air recovery have high acquisition costs, especially if they include a heat pump. The everincreasing demands on the use of primary energy from non-renewable sources mean that there is heat pump technology in the building. An economically advantageous alternative can be simple vacuum ventilation of the house, where the exhaust air from the interior is discharged directly before the suction of heat pump. Due to the better operating conditions (warmer and wetter exhaust air) the heat pump can usually achieve higher seasonal heating factors.
\end{abstract}

\section{Key words}

Energy performance of the buildings, Air-conditioning, mechanical ventilation, air distribution, simple vacuum ventilation, the heat pump suction

\section{1 ÚVOD}

Inovativní přístup se zabývá prouděním vzduchu z uzavřeného vnitřního prostoru obytných místností pomocí podtlakového provětrávání s vyústěním před sací část vnější jednotky tepelného čerpadla.Z důvodu zvyšujících se nároků na těsnost obálky budovy u novostaveb a rekonstrukcí stávajících objektů vyžadují z hygienických požadavků pro obytné místnosti průtok venkovního vzduchu - výměnu vzduchu v místnosti $0,5 \times \mathrm{h}-1,25 \mathrm{~m} / \mathrm{hod}$ na jednu osobu (ČSN EN 15665).

Splnění požadavků lze docílit pravidelnými větrání okny, nebo s ohledem na uživatelský komfort se můžeme setkat stále častěji se vzduchotechnickou jednotkou, která umožňuje zpětné získávání tepla, které předává čerstvému vzduchu z exteriéru, nebo vodě pro využití pro přípravu teplé vody anebo vytápění (větrání s tepelným 
čerpadlem). Vzduchotechnické jednotky s rekuperací vzduchu mají vysoké pořizovací náklady, obzvláště pokud obsahují tepelné čerpadlo se počáteční investice složitých a kvalitních systémů může pohybovat okolo $60000-250$ 000,- Kč [2], [3] (cena bez realizace, cena s DPH).

Stále se zvyšující nároky na využití primární energie z neobnovitelných zdrojů u novostaveb a rekonstrukcí stávajících objektů [4], [5] způsobují, že se v objektu vyskytuje technologie tepelného čerpadla, která může zajišt'ovat vytápění, chlazení a př́ípadně i př́ípravu teplé vody.

Ekonomicky výhodnou alternativou může být jednoduché podtlakové větrání domu, kdy ventilátor neobsahuje ani prostorové čidlo CO2 a odpadní vzduch z interiéru je vyústěn prŕmo před sání tepelného čerpadla typu vzduchvzduch, nebo typu vzduch voda. Vzhledem k lepším pracovním podmínkám tepelného čerpadla (teplejší a vlhčí odváděný vzduch) oproti TČ pracujícímu s venkovním vzduchem může takto pracující TČ obvykle dosahovat vyšších sezonních topných faktorů (Obr. 1) [1].

Takto navržený systém představuje úsporu na přívodním vzduchotechnickém potrubí, méně prostoru pro montáž, neobsahuje prostorově náročnou vzduchotechnickou jednotku, odvod kondenzátu, jediný zdroj hluku je samotný podtlakový ventilátor a vnější jednotka tepelného čerpadla. Odpadá potřeba údržby vzduchotechnického systému, výměna filtrů a údržba více tepelných čerpadel v objektu (Obr. 1,2).

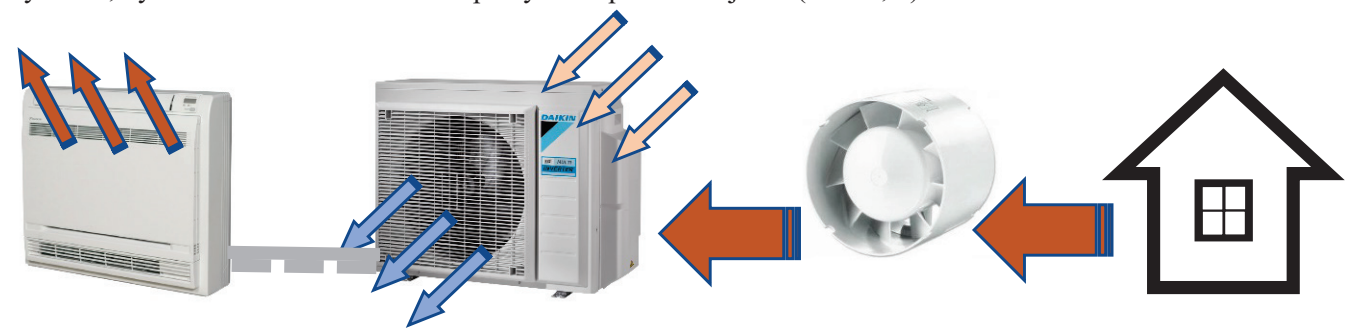

Obr. 1 Princip podtlakového provětrávání s vyústěním před sací část vnější jednotky tepelného čerpadla. Zdroj: Daikin, 4MXM-N Technical Data.

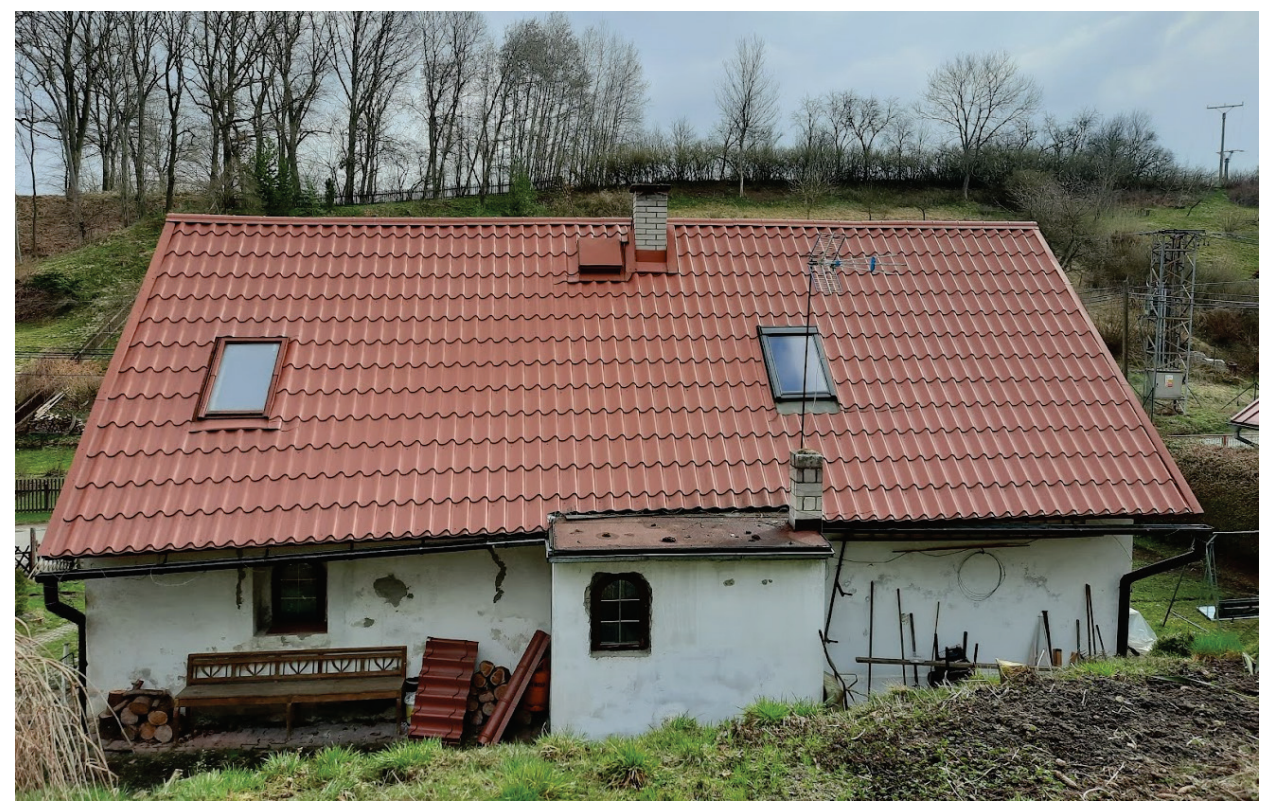

Obr. 2 Pohled na předmětný rodinný dům. Vnější jednotka tepelného čerpadla bude umístěna $\mathrm{k}$ výusti podtlakového větrání budoucí př́istavby koupelny. Zdroj: Dominik Cakl. 


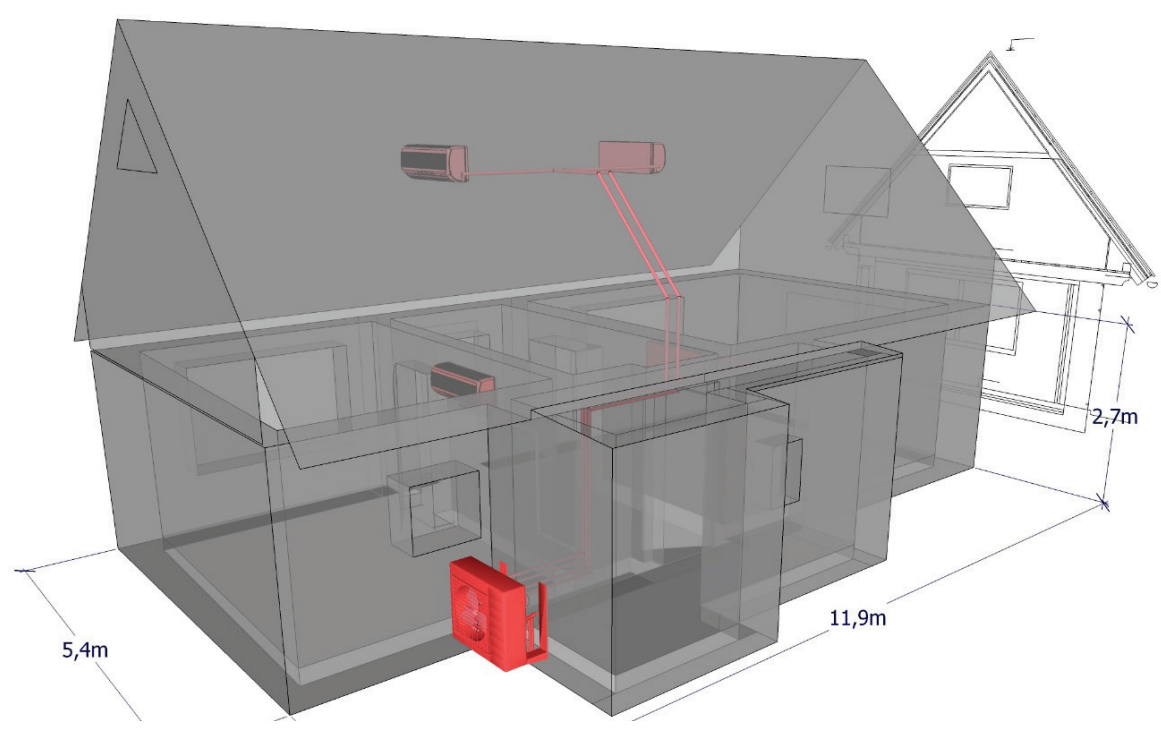

Obr. 3 Pohled na 3D model rodinného domu. Vnější jednotka tepelného čerpadla je umístěna k výusti podtlakového větrání.

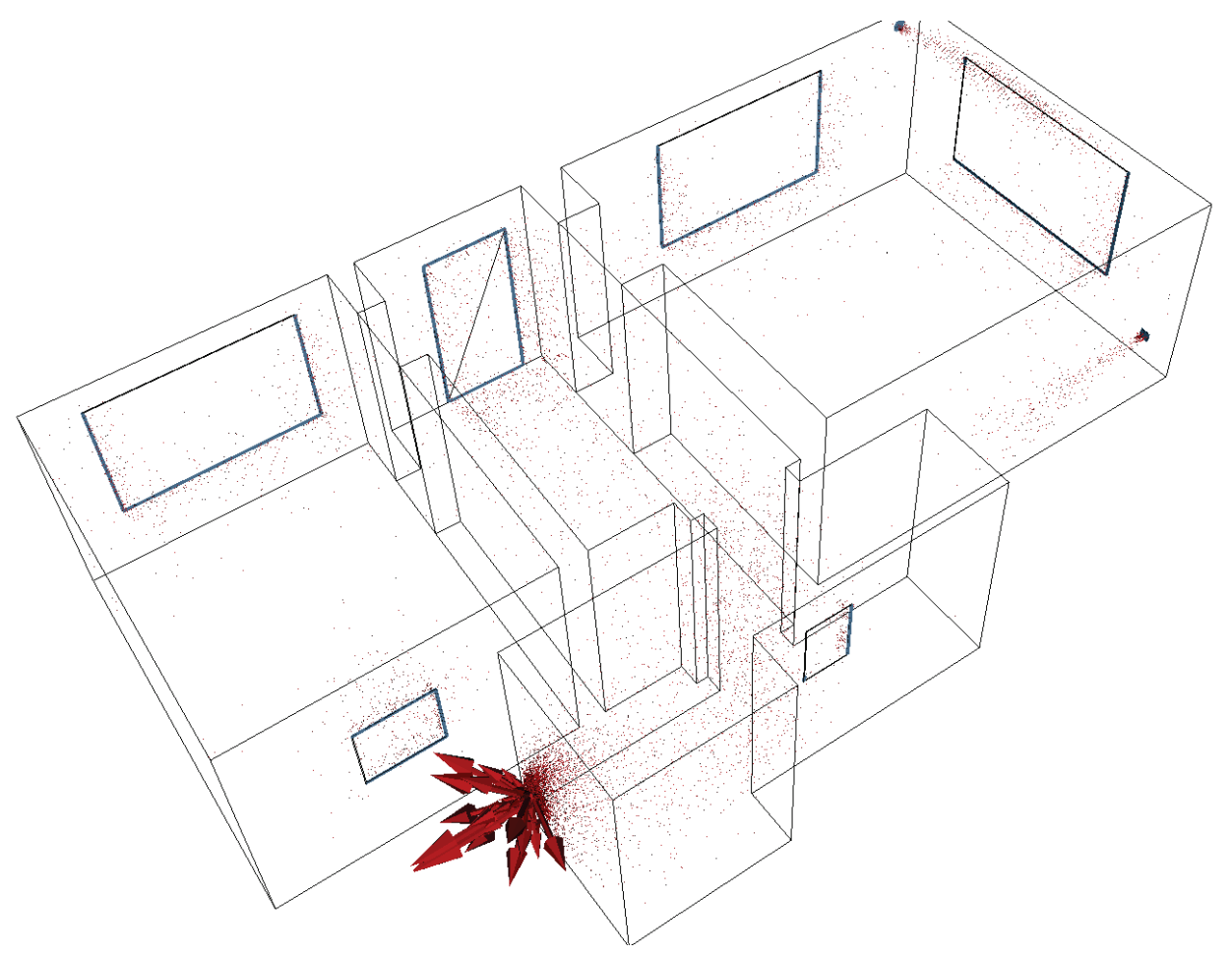

Obr. 4 Pohled na CFD model. Pohled na kaskádovité provětrání z obytných místností do chodby a následné odsávání z koupelny do exteriéru. 


\section{METODIKA}

\section{Klimatická data}

Pro hodinové rozdělení teplotních intervalů byla zvolena tabulka v závazné ČSN 730331-1, která obsahuje informativní parametry pro výpočet energetické náročnosti budov za účelem jejich hodnocení. Konkrétně tabulku "Rozdělení teplotních intervalů", kterou lze použít v př́ípadě některých bilančních výpočtů a obsahuje hodinové rozdělení teplotních intervalů v průběhu roku (Obr. 5) [7].

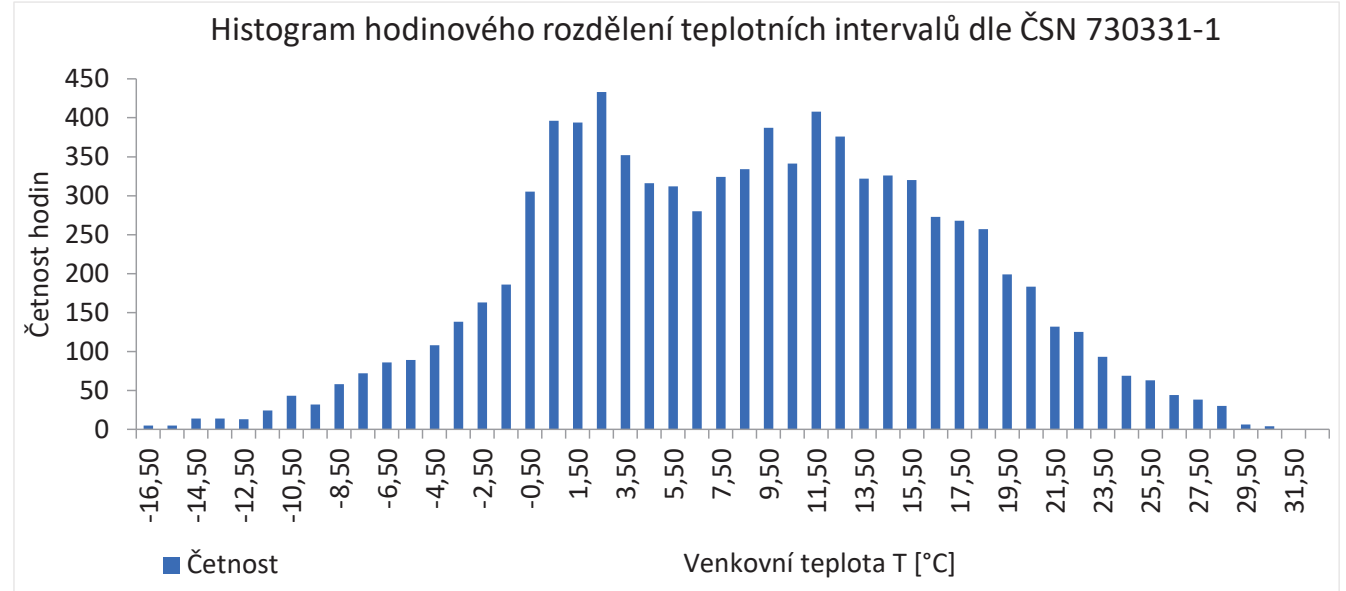

Obr. 5 Histogram hodinového rozdělení teplotních intervalů dle ČSN. Zdroj: spol. Energysim s.r.o. [7].

\section{Výpočtový model}

S ohledem na platné hygienické předpisy a s přihlédnutím na předpokládaný způsob využívání malého rodinného domu v určitém stupni komfortu byl stanoven průměrný průtok čerstvého vzduchu na $100 \mathrm{~m}^{3} / \mathrm{hod}$.

Teplota interiéru byla zvolena $20^{\circ} \mathrm{C}$. Fyzikální vlastnosti vzduchu byly uvažované neměnné. Spotřeba tepla pro pokrytí tepelné ztráty větráním byla vypočtena dle vztahu (1). Roční dodané energie pro pokrytí tepelných ztrát větráním (2). [7]

$$
\begin{gathered}
\mathrm{Q}_{\text {větraného vzduchu }}=\mathrm{V} * \frac{\varrho}{3600} * \mathrm{c} *\left(\theta_{\mathrm{e}}-\theta_{i}\right) * \mathrm{~h}, \\
\mathrm{Q}_{\text {dodané energie vlivem větrání }}=\sum \mathrm{Q}_{\text {větraného vzduchu }},
\end{gathered}
$$

Kde $Q$ je dodaná energie (kWh), $V$ je průtok vzduchu ( $\mathrm{m}^{3} /$ hod), $\varrho$, c fyzikální vlastnosti vzduchu (hustota a tepelná kapacita), $\theta e$ je teplota vzduchu v exteriéru $\left({ }^{\circ} \mathrm{C}\right), \theta \mathrm{i}$ je teplota vzduchu $\mathrm{v}$ interiéru $\left({ }^{\circ} \mathrm{C}\right), h$ počet hodin $\mathrm{v}$ roce $\mathrm{v}$ jednotlivém teplotním intervalu.

\section{VÝSLEDKY}

V této části př́spěvku jsou prezentovány výsledky spotřeby tepla na větrání při stanoveném stálém průměrném průtoku čerstvého vzduchu $100 \mathrm{~m}^{3} /$ hod. 
Tab. 1 Přehled dodávky tepla.

\begin{tabular}{|c|c|c|c|c|c|c|c|c|c|c|c|c|c|}
\hline & 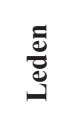 & $\stackrel{\grave{g}}{\grave{g}}$ & 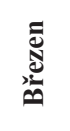 & 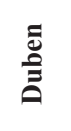 & 矛 & 己ֶౖ & U⿺辶ِ & $\stackrel{\Xi}{\mathscr{\omega}}$ & 滆 & 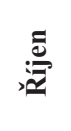 & 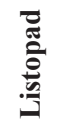 & 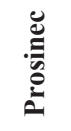 & 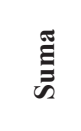 \\
\hline $\begin{array}{l}\text { Q větraného vzduchu [kWh] } \\
\text { Celkem [kWh] }\end{array}$ & 498 & 519 & 384 & 280 & 185 & 124 & 69 & 80 & 166 & 262 & 360 & 515 & 3442 \\
\hline Podíl měsíční dodávky tepla [\%] & 100 & 100 & 100 & 100 & 100 & 100 & 100 & 100 & 100 & 100 & 100 & 100 & \\
\hline \multicolumn{13}{|c|}{ Podíl roční dodané energie na vytápění pro pokrytí tepelné ztráty větráním [\%]: } & 100 \\
\hline
\end{tabular}

Níže jsou uvedeny grafy, které poukazují na podíl roční dodané energie na vytápění pro pokrytí tepelné ztráty větráním (Obr. 6, 7).

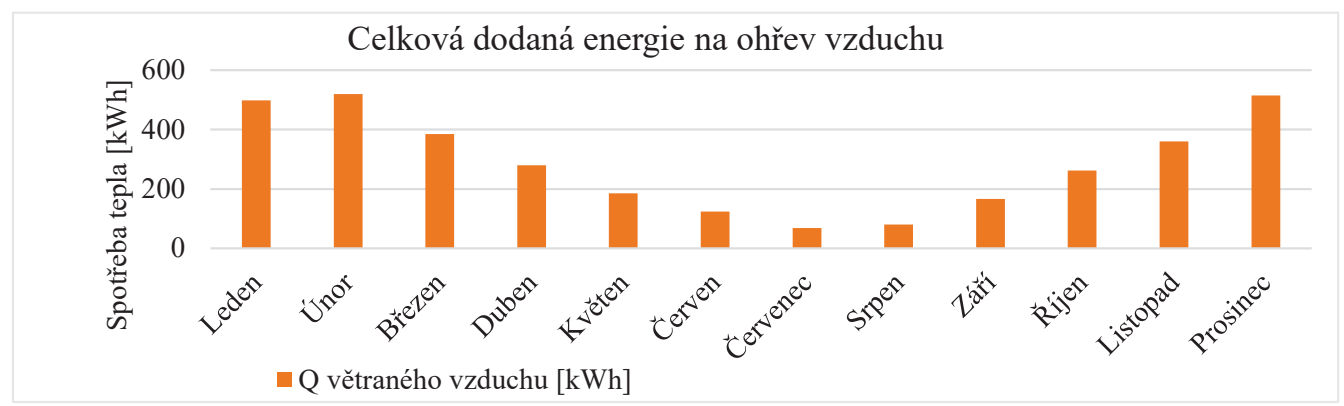

Obr. 6 Histogram hodinového rozdělení teplotních intervalů dle ČSN, doplněný o počet hodin se zapnutou protimrazovou ochranu dle typu deskového výměníku. Zdroj: spol. Energysim s.r.o., [7].

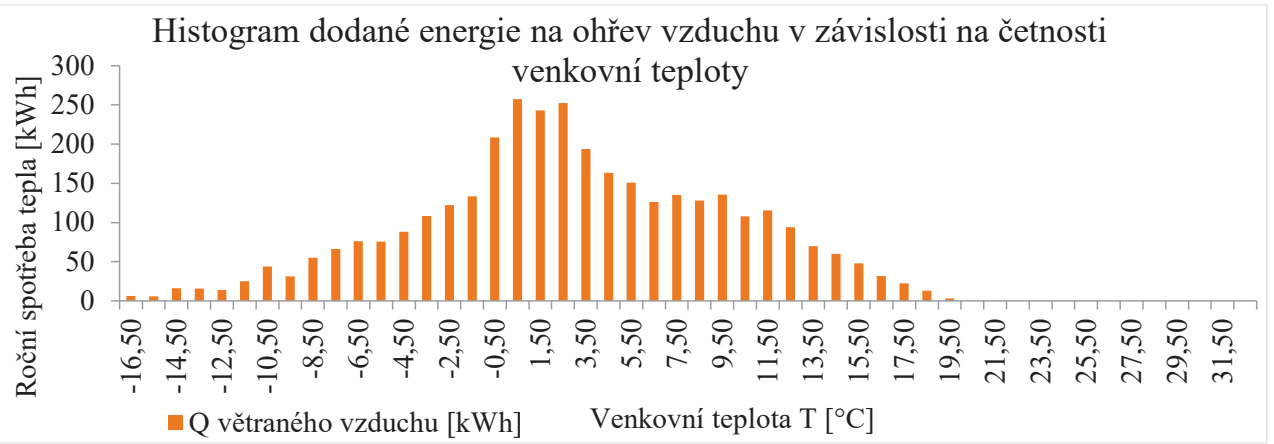

Obr. 7 Histogram hodinového rozdělení teplotních intervalů dle ČSN, doplněný o počet hodin se zapnutou protimrazovou ochranu dle typu deskového výměníku. Zdroj: spol. Energysim s.r.o., [7].

\section{DISKUZE}

V Tab. 1 bylo provedeno vyhodnocení podílů měsíční dodané energie na pokrytí tepelné ztráty větráním př̀ stanoveném stálém průměrném průtoku čerstvého vzduchu $100 \mathrm{~m} 3 /$ hod. Výpočet neuvažuje odstávku vytápění mimo topnou sezónu (od 1.9. do 31. 5.). Dobře situovaná venkovní jednotka tepelného čerpadla má potenciál tuto energii využít. Venkovní jednotka Daikin 4MXM68N má tepelný výkon $8,6 \mathrm{~kW}\left(20^{\circ} \mathrm{C} / 7{ }^{\circ} \mathrm{C}\right)$ jmenovitý průtok vzduchu 2600 m3/hod [Zdroj: Daikin, 4MXM-N Technical Data.]. Odváděný objem z místnosti tedy činí při maximálním výkonu tepelného čerpadla pouze 2,6 \% z celkového nasávaného vzduchu před vnější jednotkou. Předpokládá se dokonalé smísení a podchlazení odváděného odpadního vzduchu v průměru na alespoň vnější teplotu vzduchu. Potenciál úspory tepla, která při stanoveném stálém průměrném průtoku čerstvého vzduchu $100 \mathrm{~m}$ 3/hod činí $3442 \mathrm{kWh} /$ rok a př́ikladné ceny $2 \mathrm{Kč} / \mathrm{kWh}$ dodané energie, činí finanční úspora přes $6500 \mathrm{Kč} / \mathrm{rok}$. 


\section{DALŠÍ MOŽNÉ VYUŽITÍ PODTLAKOVÉHO VĚTRÁNÍ}

Vhodnější využití můžeme najít u budov, které mají větší průtok větracího vzduchu (panelové bytové domy, administrativní domy, výrobní objekty..) a zároveň využívají pro vytápění kombinaci různých zdroj tepla, přičemž právě kaskáda tepelných čerpadel je umístěna před výust' podtlakového větrání (Obr. 8).
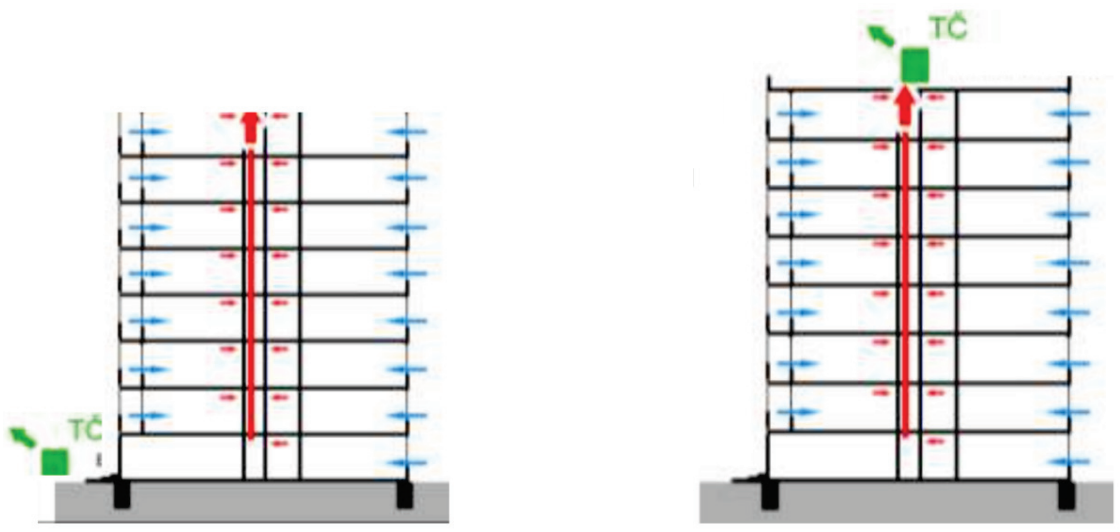

Obr. 8 Tepelné čerpadlo pro ohřev TV na venkovním vzduchu: Prostá návratnost 9-3 let. Tepelné čerpadlo pro ohřev TV na odpadním vzduchu: Prostá návratnost 7-3 let [6].

\section{ZÁVĚR}

Cílem tohoto článku bylo popsání proudění vzduchu z uzavřeného vnitřního prostoru obytných místností pomocí podtlakového provětrávání s vyústěním před sací část vnější jednotky tepelného čerpadla z důvodu zvyšujících se nároků na těsnost obálky budovy u novostaveb a rekonstrukcí stávajících objektů. Dále byl vypočítán potenciál úspory tepla, která při stanoveném stálém průměrném průtoku čerstvého vzduchu $100 \mathrm{~m} 3 /$ hod činí $3442 \mathrm{kWh} / \mathrm{rok}$.

Takto navržený systém představuje úsporu na př́vodním vzduchotechnickém potrubí, méně prostoru pro montáž, neobsahuje prostorově náročnou vzduchotechnickou jednotku, odvod kondenzátu, jediný zdroj hluku je samotný podtlakový ventilátor a vnější jednotka tepelného čerpadla. Odpadá potřeba údržby vzduchotechnického systému, výměna filtrů, údržba více tepelných čerpadel v objektu.

Dalšími kroky výzkumu by měl být výpočet sezonních topných faktorů a praktického ověření schopnosti výparníku vnější jednotky efektivního zpětného využití tepla.

\section{Použité zdroje}

[1] Martin Kny, Jan Vitouš, ČVUT v Praze, Větrací jednotky s tepelným čerpadlem, část 1. - Energetická náročnost, tzb-info.cz [online]. Datum publikování 4.5.2020. Dostupné z: https://vetrani.tzbinfo.cz/vetrani-s-rekuperaci/20606-vetraci-jednotky-s-tepelnym-cerpadlem-cast-1-energetickanarocnost

[2] Cenová nabídka jednotky NIBE F750, centrumvytapeni.cz [online]. Datum zveřejnění 10.11.2020. Dostupné z: https://www.centrumvytapeni.cz/nibe-f750-r-tepelne-cerpadlo--nerezovyzasobnik/?gclid=Cj0KCQiA-K2MBhC-

ARIsAMtLKRsPhl3gCNrr3cR7Ddp0jGFQYieIXQWOPac2J3DHMbRfSRA7WBIp6A4aAoUrEALw -wcB

[3] Cenová nabídka jednotky NIBE F750, www.nibe-shop.cz [online]. Datum zveřejnění 10.11.2020. Dostupné z: https://www.nibe-shop.cz/Ventilacni-tepelne-cerpadlo-NIBE-F750-d190.htm

[4] Vyhláška č. 78/2013 Sb.Vyhláška o energetické náročnosti budov.

[5] Vyhláška č. 264/2020 Sb.Vyhláška o energetické náročnosti budov.

[6] Jiř́ Beranovský, Karel Srdečný, Petr Vogel a kol. Pasivní panelák? A to myslíte vážně? 1. Vyd. Praha: EkoWATT, 2011. ISBN 978-80-87333-07-5.

[7] Dominik Cakl, Petr Kotek, Podíl roční dodané energie na vytápění pro doplňkový elektrický předehřev vzduchtechnických jednotek. Odborná konference Juniorstav 2020. 